\title{
Methods of adaptability and stability applied to the improvement of flooded rice
}

\author{
A.C. Silva Júnior ${ }^{1}$, V.Q. Carneiro ${ }^{1}$, I.G. $\operatorname{Santos}^{1}$, W.G Costa ${ }^{1}$, \\ G.N. Silva ${ }^{3}$, C.D. Cruz ${ }^{1}$ and P.C. Soares ${ }^{2}$ \\ ${ }^{1}$ Departamento de Biologia Geral, Universidade Federal de Viçosa, Viçosa, \\ MG, Brasil \\ ${ }^{2}$ Empresa de Pesquisa Agropecuária de Minas Gerais ,Centro Tecnológico \\ da Zona da Mata, Viçosa, MG, Brasil \\ ${ }^{3}$ Universidade Federal de Rondônia, Departamento de Matemática e \\ Estatística, JiParaná, RO, Brasil
}

Corresponding author: A.C. Silva Júnior

E-mail: antonio.silva.c.junior@gmail.com

Genet. Mol. Res. 19 (3): gmr18434

Received July 17, 2019

Accepted August 11, 2020

Published August 31, 2020

DOI http://dx.doi.org/10.4238/gmr18434

\begin{abstract}
Rice (Oryza sativa) is crop that adapts well to diverse soil and climate conditions; breeding programs have generally been committed to identifying and selecting genotypes that are stable and have high productivity in various environments. In this sense, studies of adaptability and stability are of paramount importance to aid in the recommendation of cultivars, since it allows growers to obtain detailed information about the behavior of the genotypes in each region. We evaluatde the adaptability and stability of irrigated rice genotypes grown with continuous flooding, for the selection and recommendation of cultivars for crops or breeding programs. Eighteen genotypes were evaluated for grain yield in four agricultural years at three sites, covering 12 environments. The adaptability and stability were assessed by the methods of Eberhart and Russell, multiple centroids and GGE biplot. Genotypes behaved differently regarding stability and adaptability in the different environments. Both methodologies identified BRA 02691 and MGI 0607-1 as promising to be released as cultivars; however, classification inconsistencies occurred, such as for the line BRA 031001. Multiple centroid and GGE biplot methods demonstrated greater sensitivity
\end{abstract}


than the Eberhart and Russell method. Using the methods simultaneously provides an innovative approach to the interpretation of GxE interactions and is a viable alternative for genotype classification. The genotype MGI 0607-1 showed promising behavior independent of the methodology used.

Key words: Oryza sativa; Biometry; Breeding Program; Interaction GxE

\section{INTRODUCTION}

Rice (Oryza sativa) is one of the most consumed cereals in the world, characterizing it as main source of basic food (Walter et al., 2008; Santos et al., 2019; Silva et al., 2019) for more than half the world population (Irgsp, 2005; Jacquemin et al., 2013; Zhang et al., 2013; Muthayya et al., 2014). Thus, it has great potential to reduce food insecurity (Zhou et al., 2016). With population growth, demand has increased over the years and it is estimated that by 2050 global rice production should increase from 60 to $110 \%$ to supply the demand (Godfray et al., 2010; Ray et al., 2013). Flooded rice (O. sativa) is a very important crop in Brazil (Streck et al., 2018), with about $80 \%$ of planted area in relation to rainfed crops and an annual production of $\sim 10 \mathrm{Tg}$ for the 2018 - 2019 harvest (Conab, 2019).

The most accessible way to increase the productivity of a cultivated species is through genetic improvement. The cultivar recommendation process involves the evaluation of the materials under study in environments representative of the region for which they will be recommended. Studies of the behavior of genotypes in the different evaluated environments make it possible to more accurately recommend cultivars for use in agricultural production as well as for breeding programs (Cruz, 2011).

In the evaluation of genotypes in several environments, an additional component emerges in the prediction models called the interaction between genotypic and environmental effects ( $\mathrm{G} \times \mathrm{E}$ ). According to Resende (2002), this interaction is a result of the non-additive relationship of the effects of genotypes and environments, caused by the change in the performance of the plants in different locations. The same genotype can express differential behavior throughout the environments due to the expression of its genes according to environmental influences (Cruz, 2012). However, interaction G x E studies, including the study of adaptability and stability, are fundamental for the success of the recommendation and use of cultivars (Allard and Bradshaw, 1964; Ramalho et al., 1993; Ramos et al., 2011). Adaptability is defined as the ability of genotypes to show high and constant yields in certain environments, while stability refers to the ability of genotypes to show predictable behavior against environmental fluctuations (Cruz, 2014).

Considering the recommendation of cultivars for a wide network of environments, the ideal is that they present general adaptability and high predictability to respond to environmental stimuli, as well as stability to maintain performance when environmental conditions are unfavorable to the crop, as suggested by Eberhart and Russell (1966). In the literature, there are several methodologies for assessing adaptability and stability. They differ in their biometric estimation concepts and procedures (Buitrago et al., 2011; Silva, 2012). Among these, we can mention methods that are already consolidated in the literature as those based on analysis of variance (Plaisted and Peterson, 1959; Wricke, 1965; Annicchiarico, 1992), linear regression (Finlay and Wilkinson, 1963; Eberhart and Russell, 
1966; Tai, 1971; Cruz et al., 1989), methods non-parametric (Lin and Binns, 1988; Carneiro, 1998; Rocha et al., 2005), Multiple methods centroids (Nascimento et al., 2009; Nascimento et al., 2015), mixed linear models REML/Blup (Resende, 2004), Bayesian methods (Nascimento et al., 2011, Couto et al., 2015), quantile regression (Barroso et al., 2015), Artificial Neural Networks (Barroso et al., 2013), AMMI model (Gauch, 1992) and GGE biplot (Yan et al., 2011).

The widely used methodology of Eberhart and Russell (1966) stands out for the simplicity of the calculations and information provided (Silva, 2006). This method measures the response of each genotype to variations in the environment. Another interesting approach is the multiple centroids since it is based on ideal reference values (ideotypes) created based on the experimental data to represent the genotypes of maximum general adaptability, maximum specific adaptability to favorable or unfavorable environments and the genotypes of minimum adaptability. In this method, the most adapted genotype is not necessarily the one that presents a high performance in the favorable or unfavorable environment classes, but the one that presents maximum values for one group of environments (favorable and unfavorable) and minimum for the other (Nascimento et al., 2015).

More recently, Yan et al. (2011) proposed the use of biplot graphs for the evaluation of genotypic adaptability and stability. The GGE biplot method considers the environment as a fixed effect factor in the model and, in addition, the GGE analysis groups the additive effect of genotype with the multiplicative effect of the GE interaction through techniques based on main components. The decomposition of the effects of G (Genotypes) and G X E in the model provides greater comprehensiveness of simultaneous interpretation of the main effect of genotypes and their interactions with environments. This methodology takes into account different concepts of adaptability and stability, related to the indication of representative and discriminating environments and an indication of cultivars more adapted and stable to specific environments (Gauch et al., 2008; Yan, 2011).

Thus, the objective of this study was to evaluate the adaptability and stability of irrigated rice genotypes grown under continuous flooding, for the selection and recommendation of cultivars.

\section{MATERIAL AND METHODS}

\section{Experiment information}

Eighteen lines of irrigated rice from the genetic improvement program of irrigated rice of Minas Gerais State, Brazil, were evaluated for grain yield $\left(\mathrm{kg} \cdot \mathrm{ha}^{-1}\right)$. Among the lines, five were controls (Rubelita, Seleta, Ourominas, Predileta and Rio Grande). In addition, the BRA 02691 line was recently introduced as a new cultivar, due to its superior performance in relation to the other lines within the continuous flood irrigation rice breeding program.

The experiments were conducted in the municipalities of Lambari $\left(21^{\circ} 58^{\prime} 11.24^{\prime \prime} \mathrm{S}\right.$,

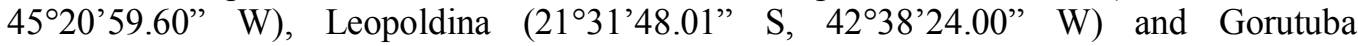
$\left(15^{\circ} 48^{\prime} 0.77^{\prime}\right.$ S S, 4317'59.09" W) for the agricultural years 2012/2013, 2013/2014, $2014 / 2015$ and 2015/2016. Each locality within each harvest was considered as an independent environment, making a total of 12 environments. 
The experimental design was a randomized block design with three replicates. The tests were conducted on floodplain soils with continuous flood irrigation. The tests were conducted on floodplain soils with continuous flood irrigation. The experimental unit consisted of four rows of five meters in length, with a spacing of $0.3 \mathrm{~m}$ and a density of 300 seeds per line. The useful area of the plots was given by the two central rows, with the $0.50 \mathrm{~m}$ of the extremities being disregarded. The cultural treatments were carried out according to the recommendations for this crop (Soares et al., 2005).

\section{Statistical Model}

Individual analyzes of variance were performed for each environment, and the means obtained were grouped by the Scott-Knott test, at 5\% probability. The analysis of joint variance was performed according to the statistical model described:

$$
\text { Yijk }=\mu+\mathrm{B} / \mathrm{Ejk}+\mathrm{Gi}+\mathrm{Ej}+\mathrm{GEij}+\varepsilon_{\mathrm{ijk}}
$$

where: $Y_{i j k}$ is the observation in the $k^{\text {th }}$ block, evaluated in the $i^{\text {th }}$ genotype and $j$-th environment; $\mu$ is the overall mean of the experiments; $\mathrm{B} / \mathrm{E}_{\mathrm{jk}}$ is the effect of block $\mathrm{k}$ within the environment $j ; G_{i}$ is the effect of the $i^{\text {th }}$ genotype; $E_{j}$ is the effect of the $j^{\text {th }}$ environment; $\mathrm{GE}_{\mathrm{ij}}$ is the effect of the interaction between genotype $\mathrm{i}$ and environment $\mathrm{j} ; \varepsilon_{\mathrm{ijk}}$ is the random error associated with observation $\mathrm{Y}_{\mathrm{ijk}}$.

Once the interaction GxE was detected, adaptability and stability analyses were performed by Eberhart and Russell (1966), Multiple Centroid (2015) and GGE biplot methodologies. All analyses were performed using the Genes application (Cruz, 2016).

\section{Methodology proposed by Eberhart and Russell (1966)}

The statistics describing the stability and adaptability of a genotype in the method of Eberhart and Russell (1966) are obtained from the model:

$$
\mathrm{Y}_{\mathrm{ij}}=\beta_{0 \mathrm{i}}+\beta_{1 \mathrm{i}} \mathrm{I}_{\mathrm{j}}+\delta_{\mathrm{ij}}+\bar{\varepsilon}_{\mathrm{ij}}
$$

In which: $Y_{i j}$ : mean of genotype $i$ in the environment $j ; \beta_{0 \mathrm{i}}$ : general mean of genotype $\mathrm{i} ; \beta_{1 \mathrm{i}}$ : linear regression coefficient, which is a measure of response of the $i^{\text {th }}$ genotype to the variation of the environment; $\mathrm{I}_{\mathrm{j}}$ : Coded environmental index; $\sum_{\mathrm{j}} \mathrm{I}_{\mathrm{j}}=0$; $\delta_{\mathrm{ij}}$ : regression deviation; $\bar{\varepsilon}_{\mathrm{ij}}$ : mean experimental error. The effect of the environment can be broken down into two components: a linear and a non-linear one. The regression coefficient of the phenotypic values of each genotype $\left(\beta_{1 i}\right)$ that is associated to the linear component, relative to the environmental index, provides estimates of adaptability parameters, while the variance component assigned to the regression deviations $\left(\sigma_{\mathrm{di}}^{2}\right)$ and the coefficient of determination $\left(\mathrm{R}^{2}\right)$ provide estimates of stability parameters.

In this work, the genotypes were distributed in five classes: I) general recommendation genotypes with production above the general average, $\beta_{1}=1.0$ and high coefficient of determination (above 70\%); II) specific recommendation to favorable environments genotypes with production above the general average, $\beta_{1}>1.0$ and coefficient of high determination; III) specific recommendation to unfavorable environments genotypes with production above the general average, $\beta_{1}<1.0$ and high coefficient of determination; IV) with restriction to the recommendation genotypes with production above the general 
average and coefficient of determination low; V) not recommended: genotypes with production below the general average.

\section{Methodology of Multiple Centroids (2005)}

For the use of this methodology the environments should be classified as favorable and unfavorable according to the environmental index proposed by Finlay and Wilkinson (1963):

$$
\mathrm{I}_{\mathrm{j}}=\frac{1}{\mathrm{~g}} \sum_{\mathrm{i}} \mathrm{Y}_{\mathrm{ij}}-\frac{1}{\mathrm{ag}} \mathrm{Y}_{\ldots}
$$

Where: $Y_{i j}=$ mean of genotypes $i$ in the environment $j ; Y_{\ldots}=$ total of observations; $a=$ number of environments; $g$ = number of genotypes. This method compares the value of Cartesian distances between genotypes in relation to four ideotypes: Ideotype I presents maximum general adaptability or maximum values observed for all the studied environments; Ideotypes II and III present maximum specific adaptability, that is, maximum response in favorable environments and minimal response in unfavorable environments (ideotype II) or maximum response in unfavorable environments and minimal in favorable environments (ideotype III); Ideotype IV shows minimal adaptability, that is, the lowest values observed in all the studied environments.

The evaluation of the differential response of the genotypes to the centroids was visualized through the first two main components, used in the original dataset containing the average of the $\mathrm{g}+4$ genotypes in each environment as described by Cruz (2014).

\section{Method GGE biplot (Genotype main effects + Genotype environment interaction)}

The biplot GGE model can be presented from the following equation:

$$
\bar{Y}_{\mathrm{ij}}-\mu_{\mathrm{j}}=\lambda_{1} \gamma_{i 1} \alpha_{j 1}+\lambda_{2} \gamma_{i 2} \alpha_{j 2}+\bar{\varepsilon}_{\mathrm{ij}}
$$

Where: $\bar{Y}_{\mathrm{ij}}$ represents the average yield of genotypes $\mathrm{i}$ in the environment $\mathrm{j} ; \mu$ is the general average productivity in environment $\mathrm{j} ; \lambda_{1} \gamma_{i 1} \alpha_{j 1}$ is the first major component IPCA $\mathrm{A}_{1}$, the effect of genotypes + interaction genotypes $\mathrm{x}$ environment; $\lambda_{2} \gamma_{i 2} \alpha_{j 2}$ is the second major component IPCA $\mathrm{A}_{2}$, of the effect of genotypes + interaction genotypes x environment; $\lambda_{1}$ and $\lambda_{2}$ are the eigenvalues associated with IPCA $A_{1}$ and IPCA $A_{2}$, respectively; $\lambda_{i 1}$ and $\lambda_{i 2}$ are the scores of the first and second main component, respectively, for the $i^{\text {th }}$ genotypes; $\alpha_{j 1}$ and $\alpha_{j 2}$ are the scores of the first and second main components, respectively for the $\mathrm{j}^{\text {th }}$ environment; $\bar{\varepsilon}_{\mathrm{ij}}$ is the model error associated with the $\mathrm{i}$-th genotypes and $\mathrm{j}^{\text {th }}$ environment (Yan and Kang, 2003).

\section{RESULTS AND DISCUSSION}

The analysis of variance revealed that the effects of GxA environments and interaction were significant, thus, there was a differential response of the genotypes to the particularities presented by the environments (Table 1). This implies that the behavior of the genotypes was influenced by the environmental conditions, justifying the use of 
methodologies that can classify the genotypes according to their adaptability and stability. However, there was no significant effect for the genotypes, which can be attributed to the fact that this set of genotypes involves materials at an advanced stage of breeding or due the high magnitude of the GxA interaction, may have masked the effect of these. Result concordant with the study by Silva et al. (2019). The estimated coefficients of variation for the characteristic were compatible with those obtained in other rice studies (Costa et al., 2002; Hosan et al., 2010; Silva et al., 2011; Streck et al., 2017; Santos et al., 2019; Silva et al., 2019), emphasizing the acceptable test quality.

The relationship between the largest and the smallest mean residual square of the environments ( $\left.\mathrm{QMr}^{+} / \mathrm{QMr}^{-}\right)$was 7.38 (Table 1). The statistical tests of Bartlett and Max F, among others, are indicated to verify the homogeneity of the residual variances. However, Gomes (1990) and Cruz, 2014 consider the residual variances homogeneous and the joint analysis adequate when the relationship $\mathrm{QMr}^{+} / \mathrm{QMr}^{-}$is less than seven. Due to the proximity to this value, they were also considered homogeneous regarding the residual variances, which makes possible the joint analysis.

Table 1. Summary of the analysis of variance of grain yield $\left(\mathrm{kg} \cdot \mathrm{ha}^{-1}\right)$ of 18 rice lines evaluated in 12 environments in the state of Minas Gerais.

\begin{tabular}{|c|c|c|c|}
\hline FV & $\mathrm{CV}$ & QMR & Probability (\%) \\
\hline Bloco/Ambiente & 24 & 3214399 & \\
\hline Genótipos (G) & 17 & 1954786 & 20.7 \\
\hline Ambientes (A) & 11 & 128702466 & 0.00 \\
\hline $\mathrm{G} \times \mathrm{A}$ & 148 & 1516798 & 0.00 \\
\hline Resíduo & 317 & 894726 & \\
\hline Média & 4925 & & \\
\hline $\mathrm{CV}(\%)$ & 19.21 & & \\
\hline $\mathrm{QMR}^{+} / \mathrm{QMR}^{-}$ & 7.38 & & \\
\hline
\end{tabular}

Only in the experimental field of Leopoldina (CELP) 2014/15 and CELP 2015/16 there was a change in the grouping pattern of the other genotypes (Table 2). However, according to Cargnin et al. (2008), the performance of rice cultivars varies according to the evaluated environments so that one cultivar is hardly the best in all cultivation conditions. The most productive lineage was BRA 02691, which group distinctly in relation to the environments considered. According to the environmental index, CELP environments 2012/13 and 2013/14 were the most favorable, while CELP 2014/15 was considered the most unfavorable. Over the years, no site has been rated only as favorable or unfavorable. The Gorutuba experimental field (CEGR), for example, presented the lowest average environmental index in the year 2015/16, but it was classified as a favorable environment on average.

Based on the strategy adopted in this work to classify the genotypes according to the method of Eberhart and Russel (1966), the genotypes were classified in only three of the five possible classes. The genotypes BRA 02691, MGI 0607-1, BRA 02708, BRA041230, BRA 031018, BRA 031001, BRA 01330 and the OUROMINAS control were classified for general environments. Already, genotypes MGI 0717-18 and BRA 031006 were indicated specifically for unfavorable environments and the other genotypes were classified as not 
recommended. This result can be explained by the average productivity estimates of these genotypes in relation to the general mean of the trials (Table 3).

Table 2. Scott-Knott group for grain yield $\left(\mathrm{kg} \cdot \mathrm{ha}^{-1}\right)$ of the 18 rice lines in each environment.

\begin{tabular}{|c|c|c|c|c|c|c|c|c|c|c|c|c|c|}
\hline \multirow{4}{*}{ Lines } & \multicolumn{12}{|c|}{ Environment } & \multirow{4}{*}{ Average } \\
\hline & E1 & E2 & E3 & $\mathbf{E 4}$ & E5 & E6 & E7 & E8 & E9 & E10 & E11 & E12 & \\
\hline & CELP & CEGR & CELB & CELP & CEGR & CELB & CELP & CEGR & CELB & CELP & CEGR & CELB & \\
\hline & $12 / 13$ & $12 / 13$ & $12 / 13$ & $13 / 14$ & $13 / 14$ & $13 / 14$ & $14 / 15$ & $14 / 15$ & $14 / 15$ & $15 / 16$ & $15 / 16$ & $15 / 16$ & \\
\hline BRA 02691 & $7327 \mathrm{a}$ & $2141 \mathrm{a}$ & $6371 \mathrm{a}$ & $8374 a$ & $5454 \mathrm{a}$ & $5633 \mathrm{a}$ & $2050 \mathrm{a}$ & $6283 \mathrm{a}$ & $5319 a$ & $3713 \mathrm{~b}$ & $5789 a$ & $5166 \mathrm{a}$ & 5302 \\
\hline MGI 0717-18 & $5913 \mathrm{a}$ & $2973 \mathrm{a}$ & $6292 \mathrm{a}$ & $8220 \mathrm{a}$ & $6029 \mathrm{a}$ & $5930 \mathrm{a}$ & $3683 \mathrm{a}$ & $5152 \mathrm{a}$ & $5060 \mathrm{a}$ & $4591 \mathrm{a}$ & $5009 \mathrm{a}$ & $4735 \mathrm{a}$ & 5299 \\
\hline OUROMINAS & $7091 \mathrm{a}$ & $2708 \mathrm{a}$ & $5958 \mathrm{a}$ & $7487 \mathrm{a}$ & $4565 \mathrm{a}$ & $7033 \mathrm{a}$ & $3172 \mathrm{a}$ & $4281 \mathrm{a}$ & $5889 \mathrm{a}$ & $4227 \mathrm{a}$ & $6024 \mathrm{a}$ & $4302 \mathrm{a}$ & 5228 \\
\hline MGI0607-1 & $7580 \mathrm{a}$ & $2704 \mathrm{a}$ & $6338 \mathrm{a}$ & $7564 \mathrm{a}$ & $5091 \mathrm{a}$ & $5194 \mathrm{a}$ & $3041 \mathrm{a}$ & $4105 \mathrm{a}$ & $6278 \mathrm{a}$ & $4555 \mathrm{a}$ & $5573 \mathrm{a}$ & $3541 \mathrm{a}$ & 5130 \\
\hline BRA 02708 & $7502 \mathrm{a}$ & 2547 a & $6501 \mathrm{a}$ & $7841 \mathrm{a}$ & 2993 a & $4848 \mathrm{a}$ & 3824 a & $4633 \mathrm{a}$ & $5453 \mathrm{a}$ & $4586 \mathrm{a}$ & 5093 a & $4504 \mathrm{a}$ & 5027 \\
\hline BRA 041230 & $6692 \mathrm{a}$ & $2582 \mathrm{a}$ & $6468 \mathrm{a}$ & $8083 \mathrm{a}$ & $4338 \mathrm{a}$ & $5647 \mathrm{a}$ & 2996 a & $2817 \mathrm{a}$ & $5704 \mathrm{a}$ & $4639 a$ & $5995 \mathrm{a}$ & $4137 \mathrm{a}$ & 5008 \\
\hline BRA 031006 & $6101 \mathrm{a}$ & $3060 \mathrm{a}$ & $6088 \mathrm{a}$ & 7439 a & 3829 a & $6679 \mathrm{a}$ & $4280 \mathrm{a}$ & $3595 \mathrm{a}$ & $4786 \mathrm{a}$ & $4855 \mathrm{a}$ & $5103 \mathrm{a}$ & $4025 \mathrm{a}$ & 4987 \\
\hline BRA 031018 & $7585 \mathrm{a}$ & $2874 \mathrm{a}$ & $5597 \mathrm{a}$ & $7602 \mathrm{a}$ & $5136 \mathrm{a}$ & $5378 \mathrm{a}$ & $3415 \mathrm{a}$ & $3447 \mathrm{a}$ & $5129 \mathrm{a}$ & $5309 \mathrm{a}$ & $4524 \mathrm{a}$ & $3767 \mathrm{a}$ & 4980 \\
\hline BRA 031001 & $7535 \mathrm{a}$ & $3212 \mathrm{a}$ & $5875 \mathrm{a}$ & $8271 \mathrm{a}$ & $4290 \mathrm{a}$ & $4898 \mathrm{a}$ & $3520 \mathrm{a}$ & $3521 \mathrm{a}$ & $4981 \mathrm{a}$ & $4250 \mathrm{a}$ & $5794 \mathrm{a}$ & $3567 \mathrm{a}$ & 4976 \\
\hline BRA 01330 & $6893 \mathrm{a}$ & $3123 \mathrm{a}$ & $5676 \mathrm{a}$ & $7209 a$ & $4680 \mathrm{a}$ & $6327 \mathrm{a}$ & $2940 \mathrm{a}$ & $3355 \mathrm{a}$ & $5667 \mathrm{a}$ & $4282 \mathrm{a}$ & $5857 \mathrm{a}$ & $3573 \mathrm{a}$ & 4965 \\
\hline SELETA & $6553 \mathrm{a}$ & 2974 a & $5986 \mathrm{a}$ & $7150 \mathrm{a}$ & $5717 \mathrm{a}$ & $5850 \mathrm{a}$ & $1638 \mathrm{c}$ & $3141 \mathrm{a}$ & $5208 \mathrm{a}$ & $3414 \mathrm{~b}$ & $6397 \mathrm{a}$ & $4878 \mathrm{a}$ & 4909 \\
\hline BRA 041099 & $6146 \mathrm{a}$ & $2507 \mathrm{a}$ & $5880 \mathrm{a}$ & $7140 \mathrm{a}$ & $4083 \mathrm{a}$ & $5941 \mathrm{a}$ & $1992 \mathrm{~b}$ & $3540 \mathrm{a}$ & $6158 \mathrm{a}$ & $3662 \mathrm{~b}$ & $6407 \mathrm{a}$ & $4556 \mathrm{a}$ & 4834 \\
\hline RIO GRANDE & $6826 \mathrm{a}$ & $2202 \mathrm{a}$ & $6121 \mathrm{a}$ & $7320 \mathrm{a}$ & $4824 \mathrm{a}$ & $6738 \mathrm{a}$ & $1461 \mathrm{c}$ & $3735 \mathrm{a}$ & $5500 \mathrm{a}$ & $3504 \mathrm{~b}$ & $5956 \mathrm{a}$ & $3789 a$ & 4831 \\
\hline CNAI 9091 & $7283 \mathrm{a}$ & 2437 a & $5059 \mathrm{a}$ & $6964 \mathrm{a}$ & $4511 \mathrm{a}$ & 5939 a & $2461 \mathrm{~b}$ & $3503 \mathrm{a}$ & $4851 \mathrm{a}$ & $3749 \mathrm{~b}$ & $6098 \mathrm{a}$ & $4730 \mathrm{a}$ & 4799 \\
\hline BRA 041236 & $6679 a$ & $2943 \mathrm{a}$ & $5875 \mathrm{a}$ & $6927 \mathrm{a}$ & $4283 \mathrm{a}$ & $4927 \mathrm{a}$ & $3031 \mathrm{a}$ & $4049 a$ & $4833 \mathrm{a}$ & $3910 \mathrm{~b}$ & $4750 \mathrm{a}$ & $3358 \mathrm{a}$ & 4631 \\
\hline RUBELITA & $6592 \mathrm{a}$ & $3119 a$ & $6315 \mathrm{a}$ & $8372 \mathrm{a}$ & $2439 \mathrm{a}$ & $5348 \mathrm{a}$ & $1196 \mathrm{c}$ & $3169 \mathrm{a}$ & $5908 \mathrm{a}$ & $3591 \mathrm{~b}$ & $5372 \mathrm{a}$ & $3998 \mathrm{a}$ & 4618 \\
\hline PREDILETA & $6610 \mathrm{a}$ & $2580 \mathrm{a}$ & $5713 \mathrm{a}$ & $7565 \mathrm{a}$ & $4748 \mathrm{a}$ & $5552 \mathrm{a}$ & $1245 \mathrm{c}$ & $2372 \mathrm{a}$ & $5629 \mathrm{a}$ & $3447 \mathrm{~b}$ & $4564 \mathrm{a}$ & $4720 \mathrm{a}$ & 4562 \\
\hline BRA 02706 & $6491 \mathrm{a}$ & $2118 \mathrm{a}$ & $5440 \mathrm{a}$ & $7860 \mathrm{a}$ & $3955 \mathrm{a}$ & $4520 \mathrm{a}$ & $1022 \mathrm{c}$ & $4170 \mathrm{a}$ & $5370 \mathrm{a}$ & $3330 \mathrm{~b}$ & $5598 \mathrm{a}$ & $4848 \mathrm{a}$ & 4560 \\
\hline MÉDIA & 6855 & 2711 & 5975 & 7633 & 4498 & 5688 & 2609 & 3826 & 5429 & 4090 & 5550 & 4233 & 4925 \\
\hline $\mathrm{CV}$ & 13.14 & 17.73 & 13.89 & 11.22 & 29.02 & 14.32 & 19.76 & 25.63 & 15.63 & 16.77 & 15.45 & 14.1 & \\
\hline & 1931 & -2214 & 1050 & 2707 & -426 & 17.02 & -2315 & 1098 & & (1) & & -691 & \\
\hline
\end{tabular}

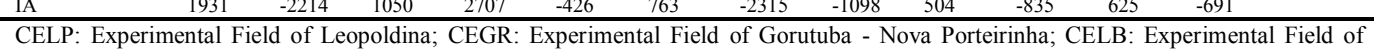
Lambari; CV: Coefficient of variation; IA: Environmental Index; The averages followed by the same letter in each column indicate homogeneous groups, at the 5\% probability level, by the original Scott-Knott test; E: Environment.

Table 3. Estimation of mean grain yield $\left(\mathrm{kg} \cdot \mathrm{ha}^{-1}\right)\left(\widehat{\beta_{0}}\right)$, regression coefficient $\left(\widehat{\beta_{1}}\right)$, regression deviation $\left(\sigma_{\text {di }}^{2}\right)$ and coefficient of determination $\left(\mathrm{R}^{2} \%\right)$ for 18 lines of flooded rice in Minas Gerais in 12 environments by the methodology of Eberhart and Russell.

\begin{tabular}{|c|c|c|c|c|c|}
\hline Lines & $\widehat{\beta_{0}}$ & $\widehat{\beta_{1}}(1)$ & $\sigma_{\mathrm{di}}^{2} \times 10^{3}(2)$ & $\mathbf{R}^{2}(\%)$ & Class \\
\hline BRA 02691 & $5.302+$ & $1.0956^{n s}$ & $533.968 * *$ & 80.43 & I \\
\hline OUROMINAS & $5.228+$ & $0.9852^{n s}$ & $-55.148^{\mathrm{ns}}$ & 93.51 & I \\
\hline MGI 0607-1 & $5.130+$ & $1.0079^{\mathrm{ns}}$ & $11.323^{\mathrm{ns}}$ & 91.63 & I \\
\hline BRA 02708 & $5.027+$ & $0.9297^{n s}$ & $382.008 * *$ & 78.69 & I \\
\hline BRA041230 & $5.008+$ & $1.0757^{n s}$ & $-28.216^{\mathrm{ns}}$ & 93.51 & I \\
\hline BRA 031018 & $4.980+$ & $0.8902^{n s}$ & $217.373^{*}$ & 82.23 & I \\
\hline BRA 031001 & $4.976+$ & $0.9921^{n s}$ & $109.789^{\mathrm{ns}}$ & 88.31 & I \\
\hline BRA 01330 & $4.965+$ & $0.9416^{n s}$ & $-58.964^{\mathrm{ns}}$ & 93.08 & I \\
\hline MGI 0717-18 & $5.298+$ & $0.7644^{*}$ & $219.603^{*}$ & 77.24 & III \\
\hline BRA 031006 & $4.987+$ & $0.7595^{*}$ & $237.714^{*}$ & 76.31 & III \\
\hline SELETA & 4.909 & $1.0259^{n s}$ & $261.954^{*}$ & 84.82 & V \\
\hline BRA 041099 & 4.834 & $1.0305^{n s}$ & $60.930^{\mathrm{ns}}$ & 90.49 & V \\
\hline RIO GRANDE & 4.831 & $1.1862^{*}$ & $29.201^{\mathrm{ns}}$ & 93.39 & V \\
\hline CNAI 9091 & 4.799 & $0.9822^{n s}$ & $21.359^{\mathrm{ns}}$ & 84.82 & V \\
\hline BRA 041236 & 4.631 & $0.8235^{*}$ & $-93.328^{\mathrm{ns}}$ & 92.78 & V \\
\hline RUBELITA & 4.618 & $1.2391^{*}$ & $330.156^{* * *}$ & 87.75 & V \\
\hline PREDILETA & 4.562 & $1.1368^{n s}$ & $148.166^{\mathrm{ns}}$ & 89.91 & V \\
\hline BRA 02706 & 4.560 & $1.1338^{n s}$ & $169.866^{\mathrm{ns}}$ & 89.35 & V \\
\hline
\end{tabular}

$(+)$ Values above the general average. $(1) *$ and ${ }^{* *}$ : significant at $5 \%$ and $1 \%$ of probability, respectively, by the $\mathrm{t}$-test; ns, not significant. (2) $*$ and $* *$, significant at $5 \%$ and $1 \%$ of probability, respectively, by the $\mathrm{F}$; ns, non-significant test. 
Regarding the controls, all were classified in class V, except for OUROMINAS control. Her mean may have influenced negatively, which culminated in this classification or, still, the genotypes under test were so superior that they raised the means to levels higher than those established by the own controls, which indicates a promising recommendation of the future cultivars launched by the program.

From all the environments evaluated E2 (CEGR 12/13), E5 (CEGR 13/14), E7 (CELP 14/15), E8 (CEGR 14/15), E10 (CELP 15/16) and E12 (CELB 15/16) were classified as unfavorable since they obtained a lower average than the general average (Table 2). For these environments, the genotypes to be recommended should be more rustic and have high stability, which is usually associated with lower yields. The other environments classified as favorable require adapted genotypes that have the capacity to respond to environmental improvement (Borges et al., 2010).

According to the Centroid method, the Rubelita, Seleta and Rio Grande controls were classified as specific adaptability to favorable environments. The OUROMINAS control presented high general adaptability and Predileta control considered to be low adapted (Table 4). Different result for the Predileta control was obtained by Silva et al. (2008). The authors used the method proposed by Cruz et al. (1989) and obtained high general adaptability classification for this cultivar. The line BRA 02691 was classified as high general adaptability by the Multiple Centroid method (Table 4). This lineage was recently launched, as a cultivar of good productive potential, to the producers of irrigated rice of state Minas Gerais-MG, Brazil, which proves its high performance. Another lineage that achieved similar performance was MGI 0607-1, promising as a new cultivar.

The method of the Multiple Centroids showed homogeneous distribution of the genotypes in the central centroids (Figure 1), indicating that most of them have general adaptability (Carvalho et al., 2002). This is because of the lower the difference between a given genotype and an ideotype 1, the smaller the difference between this genotype and that of maximum performance in all environments (Rocha et al., 2005).

The visual grouping of environments based on the $\mathrm{G} \times \mathrm{E}$ cross between the best genotypes is shown in Figure 2. The vertices of the polygon are formed by genotypes G3 (BRA 02691), G12 (MGI 0717-18), G14 (BRA 031006), G4 (RUBELITA) and G6 (BRA 02706). The environment domes were cut in 4 groups by the lines that came out of the origin of the biplot. Thus, the groups are formed by (i) E8 (CEGR 14/15), E5 (CEGR 13/14), E12 (CELB 15/16), E6 (CELB 13/14) and E11 (CEGR 15/16); (ii) E9 (CELB 14/15); (iii) E2 (CEGR 12/13), E10 (CELP 15/16), E7 (CELP 14/15) and E1 (CELP 12/13); (iv) E3 (CELB 12/13) and E4 (CELP 13/14).

The genotypes G2 (BRA 041099) is the vertex of the sector in which the environment E9 (CELB 14/15) is allocated and, therefore, the genotype that had better performance in this environment; the G4 (RUBELITA) is the vertex in the sector where E9 (CELB 14/15) are allocated, these are the most adapted genotypes in these environments. However, the genotype G3 (BRA 02691) obtained result was similar when associated with environments E8 (CEGR 14/15), E5 (CEGR 13/14) and E12 (CELB 15/16) (Figure 2). In the sectors of G9 (CNAI 9091), G6 (BRA 02706) and G18 (RIO GRANDE) do not contain allocated environments, since these genotypes are the worst in relation to productivity in some or all environments. 


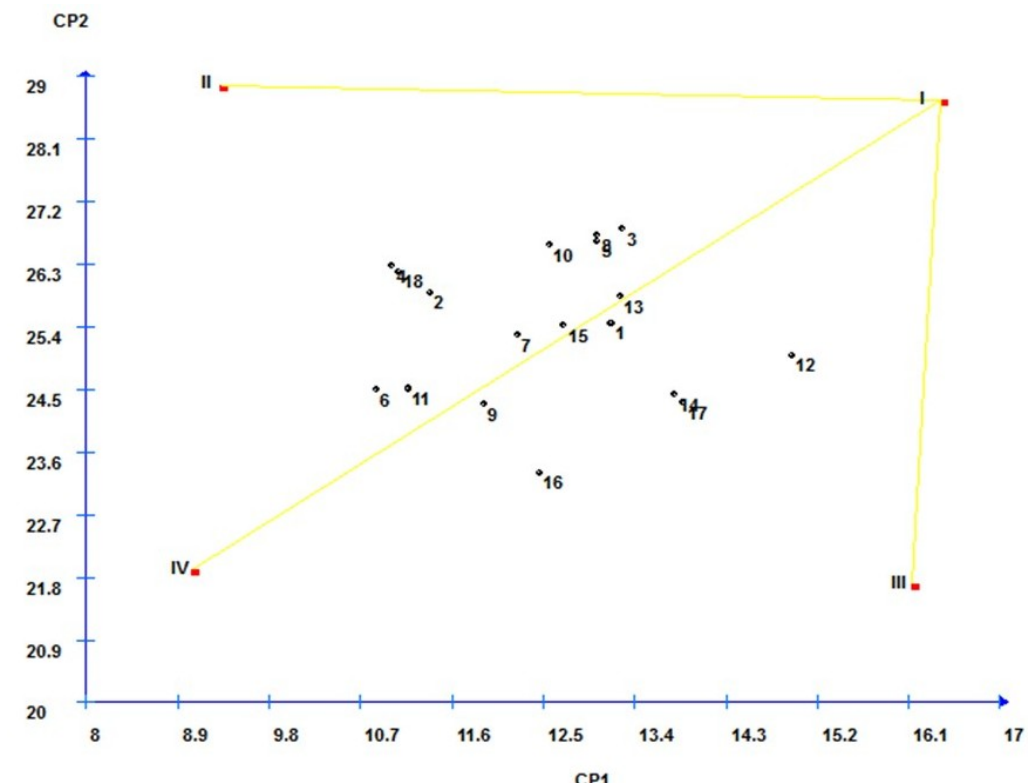

Figure 1. Graphical dispersion of the 18 genotypes of flooded rice, in relation to two main components, for grain yield variable in 12 environments. The four red dots represent the ideotypes. I: High general adaptability; II: Specific adaptability to favorable environments; III: Specific adaptability to unfavorable environments and IV: Little adapted. CP1, main component 1; CP2, main component 2.

Which Won Where/What

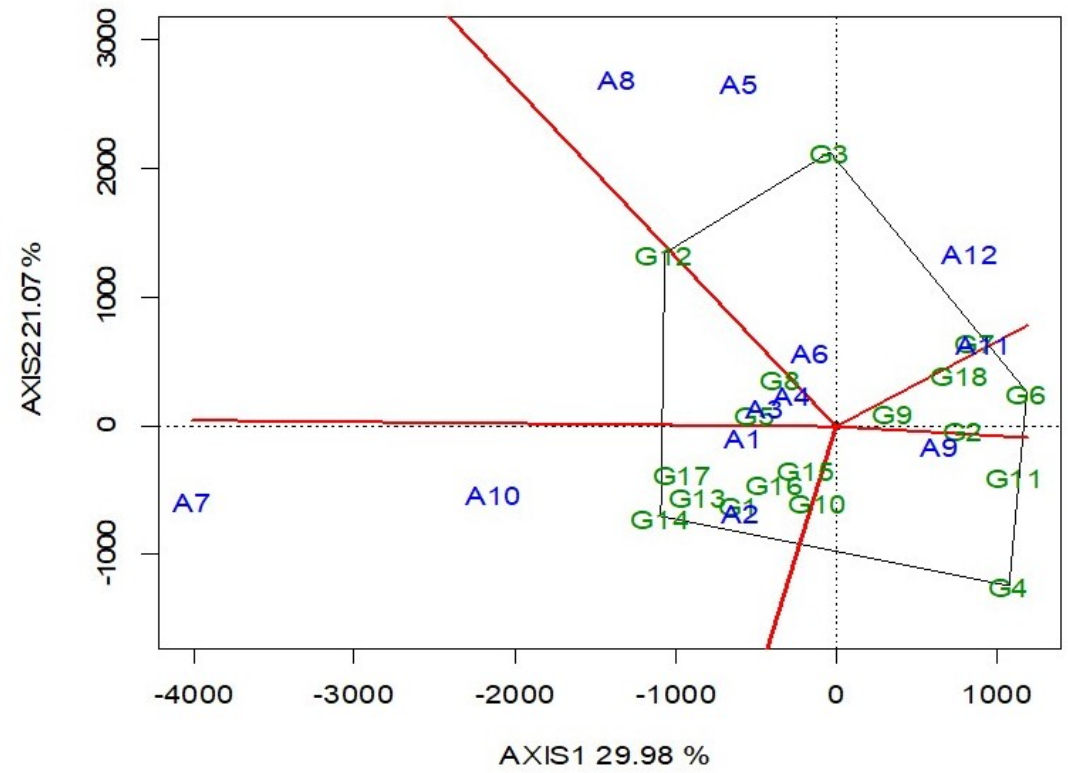

Figure 2. GGE Biplot ("Which-won-where") for 18 genotypes of flooded rice in relation to grain yield (kg / ha) in 12 environments, which genotypes showed better performance in environments. 
Compare two Genotypes

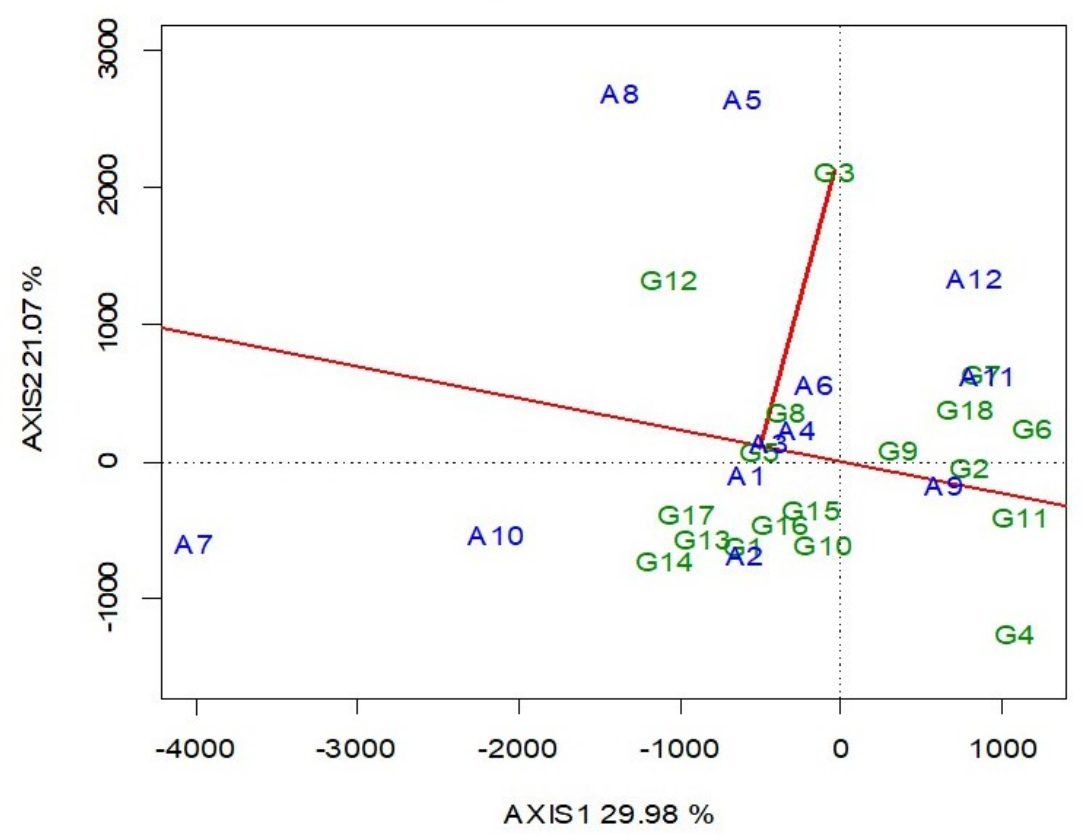

Figure 3. GGE biplot for comparison between two genotypes of flooded rice.

In GGE biplot analysis two genotypes can be visually compared by connecting them to a straight line and then tracing a perpendicular line passing through the biplot origin (Figure 3). This perpendicular line is the "line of equality" of the two genotypes. However, the two genotypes to be compared must be the same in all environments located on this line. As the biplot distance of the line connecting the two genotypes measures the Euclidean distance between them, the comparison using the method shown in Figure 3 is significant considering that the connecting line is not so long. The genotype has higher values in environments located on the side of the equality line.

From the point of view of genotype classification, the central circle (Figure 4) represents the ideal genotype with high productivity, good adaptability, and good stability in the group of environment tested. Considering the parameters together, the genotype that presents both high production value and good adaptability and stability was G12 (MGI 0717-18) (Figure 4). On the other hand, the least stable and productive in all environments were G4 (RUBELITA), G11 (PREDILETA) and G6 (BRA 02706) (Figure 4).

In Figure 5, the two firsts major component is represented and the percentage change information explained by two major components correspond to $51 \%$. The cosine of the angle between the vectors of two environments equals the correlation between them (Yan and Tink, 2006). Thus, it is found that the environment A5 (CEGR 13/14) and A8 (CEGR 14/15), A7 (CELP 14/15) and A10 (CELP 15/16) are positively correlated. 


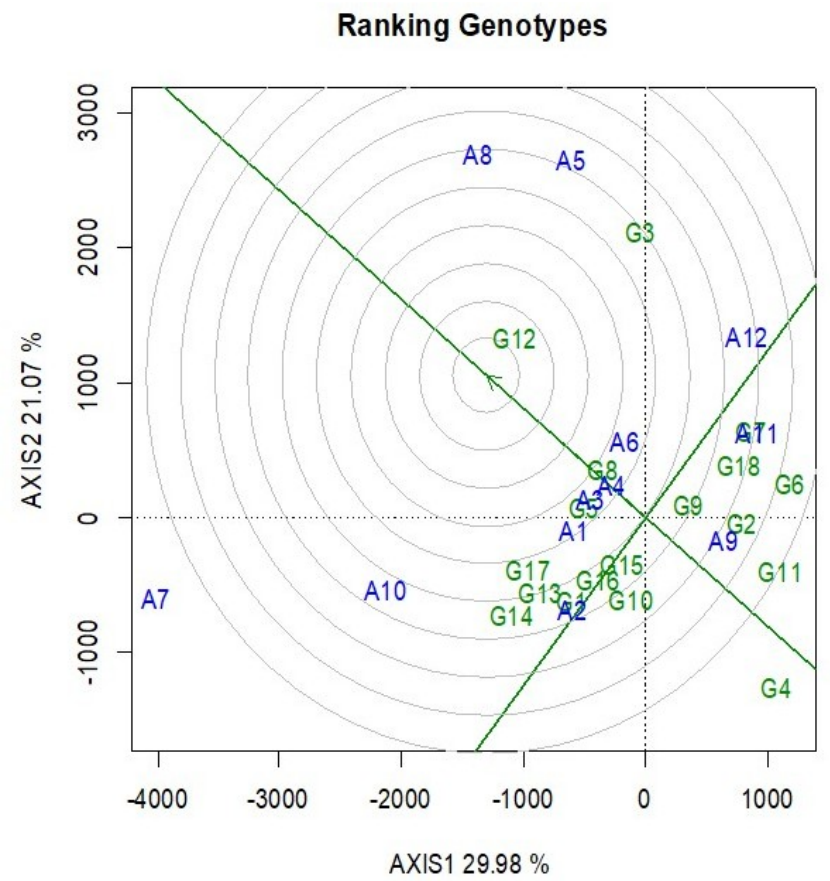

Figure 4. GGE Biplot 'Ranking Genotpypes' of 18 genotypes of flooded rice evaluated in 12 environments in Minas Gerais.

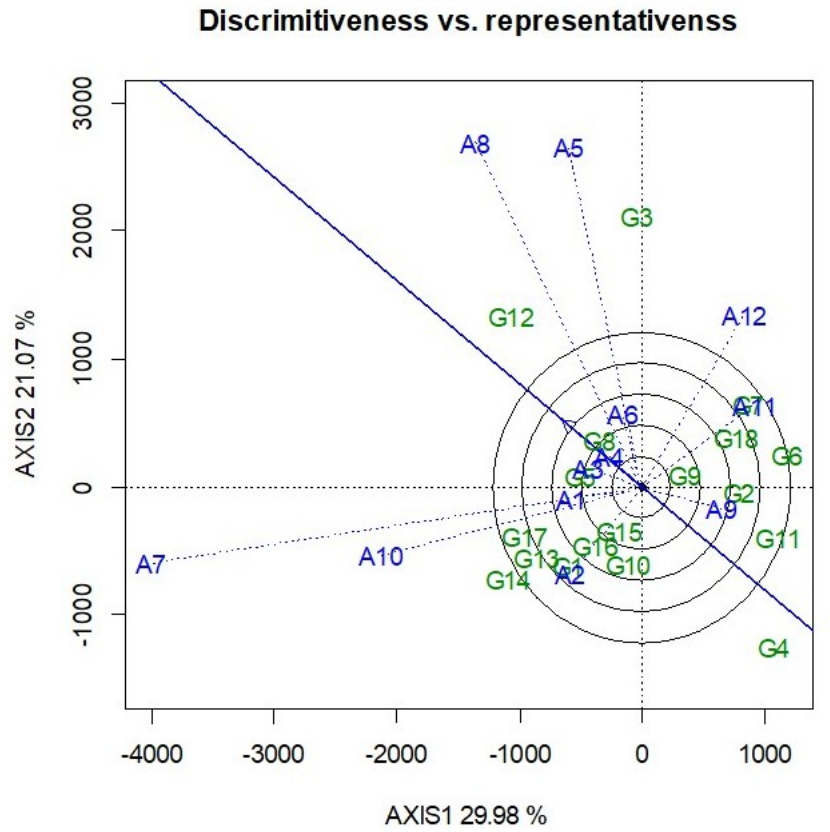

Figure 5. Discrimination and representativeness of the environments for 18 lines of flooded rice in 12 environments in Minas Gerais. 
The GGE biplot visualization "Mean versus Stability" is an effective tool for the evaluation of genotypes in both aspects (Yan et al., 2007; Yan, 2011). In Figure 6, the small "arrow" represent the "average environment" and are related by the average coordinates of all test environments in the biplot. One way to evaluate the average performance for the genotype about this mean versus stability is through the arrow that points to the greater variability of performance, that is, less stability in both the direction in which this arrow is being pointed.

The productivity and stability of the genotypes are evaluated from the environmental coordinate (Yan and Kang, 2002). In this method, the ideal environment is defined in Figure 6, from the mean scores of the major components 1 and 2 and all environments, represented in the graph by a small circle. Genotype G3 (BRA 02691) as highly unstable since it has a lower than expected yield in the A7 environment (CELP 14/15) and A10 (CELP 15/16) while producing relatively well in A5 (CEGR 13/14), A8 (CEGR 14/15) and A12 (CELB 15/16). Highlight for the genotype G9 (CNAI 9091) which was stable and with slightly above average productivity. Note that if the biplot explains only a proportion of the total variation, some stable genotypes may not be truly stable as their variations can be explained in this biplot.

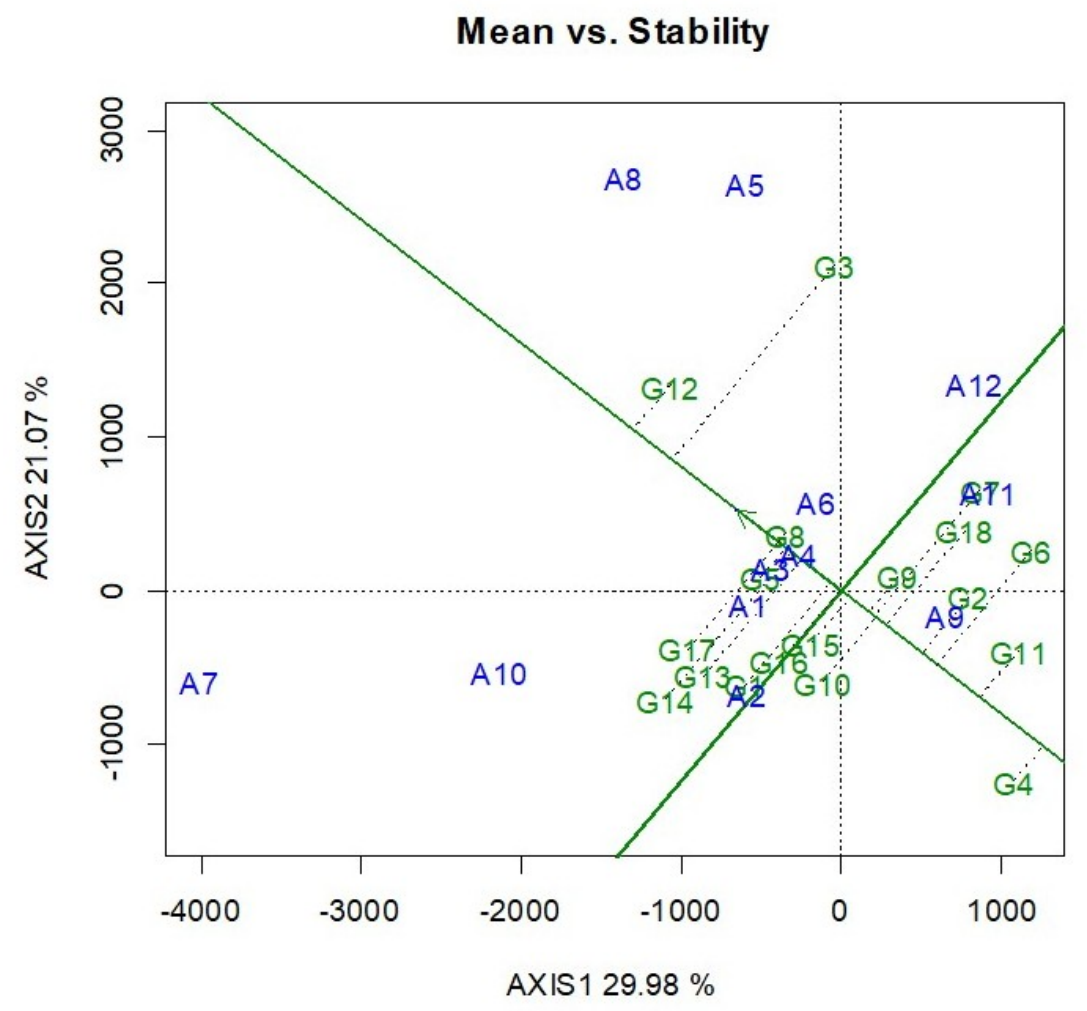

Figure 6. Representation of the mean and stability values obtained by GGE Biplot, indicating the genotype productivity ranking, and its respective productive stability of 18 lines of flooded rice in Minas Gerias evaluated in 12 environments. 
It was observed by the methods used that genotypes with high productivity means are generally classified as high general adaptability, as in the case of BRA 02691, MGI 0607-1 and the Ourominas control. However, classification inconsistencies occurred, as BRA 031001, classified as highly adaptable by the Eberhart and Russell method and low adapted by the centroid method.

Another example is the classification of the Rubelita control, which was considered not recommended by the method of Eberhart and Russell, but indicated for favorable environments by the centroid method. When examining the pertinence expressed by the probabilities of belonging to each group in the centroid method (Table 4), this control presented a fairly close probability for classes II (adaptability to unfavorable environments) and IV (not adapted).

Table 4. Classification of 18 rice lines evaluated in 12 environments in the state of Minas Gerais. Observed by the centroid method (Rocha et al., 2005).

\begin{tabular}{|c|c|c|c|c|c|}
\hline Lines & I & II & III & IV & Class \\
\hline BRA 2691 & 0.331 & 0.205 & 0.275 & 0.189 & I \\
\hline MGI 0717-18 & 0.319 & 0.16 & 0.357 & 0.164 & III \\
\hline OUROMINAS & 0.314 & 0.259 & 0.225 & 0.202 & I \\
\hline MGI 0607-1 & 0.282 & 0.243 & 0.252 & 0.223 & I \\
\hline BRA 2708 & 0.254 & 0.239 & 0.262 & 0.245 & III \\
\hline BRA 41230 & 0.235 & 0.298 & 0.212 & 0.255 & II \\
\hline BRA 31006 & 0.258 & 0.236 & 0.265 & 0.241 & III \\
\hline BRA 31018 & 0.254 & 0.219 & 0.288 & 0.24 & III \\
\hline BRA 31001 & 0.244 & 0.255 & 0.245 & 0.256 & IV \\
\hline BRA 1330 & 0.246 & 0.278 & 0.226 & 0.25 & II \\
\hline SELETA & 0.238 & 0.27 & 0.231 & 0.261 & II \\
\hline BRA 41099 & 0.213 & 0.31 & 0.201 & 0.277 & II \\
\hline RIO GRANDE & 0.218 & 0.331 & 0.193 & 0.259 & II \\
\hline CNAI 9091 & 0.226 & 0.267 & 0.232 & 0.276 & IV \\
\hline BRA 41236 & 0.207 & 0.222 & 0.268 & 0.304 & IV \\
\hline RUBELITA & 0.153 & 0.367 & 0.15 & 0.33 & II \\
\hline PREDILETA & 0.18 & 0.282 & 0.194 & 0.344 & IV \\
\hline BRA 2706 & 0.188 & 0.26 & 0.212 & 0.341 & IV \\
\hline
\end{tabular}

When Eberhart and Russel classes V and IV of the centroid are considered to be equivalent, classification coincides in $28 \%$ of the genotypes, which means that the methods present singularities when ranking the lineages and that the choice of the best technique biometrics to be employed in adaptability and stability studies should be done judiciously. In all cases, the classification in each of the methods has to be carefully evaluated, considering the subjectivity in establishing the classification referenced in this study, by the method of Eberhart and Russell, and by the decision of the most pertinence, taking into account values of near probability obtained by the centroid method.

As for GGE biplot, it is observed that this procedure helps the researcher to understand the behavior of the genotypes, the environment and the interaction of this one so that decisions can be made regarding the criterion of selection and recommendation. However, comparing the genotype G3 (BRA 02691) that obtained better performance in the 
multiple centroid method and Eberhart and Russell (1966) showing higher yield in all environments, into GGE biplot this genotype was highly unstable. This reinforces the simultaneous use of adaptability and stability methods for the interpretation of genotype $\mathrm{x}$ environment interaction.

From the point of view of these results, we stress that different methods may present different classifications when ranking genotypes so that the use of more than one methodology would give greater credibility to the results. The methodologies used in this study should be used together to complement the information and to obtain conclusions with more rigor in the breeding programs, to assist in the selection and recommendation of lineages as new cultivars.

\section{CONCLUSIONS}

Using the methods simultaneously provides an innovative approach to the interpretation of the adaptability and stability of irrigated rice genotypes. The genotype MGI 0607-1 showed promising behavior independent of the methodology used.

Some inconsistencies can be found when studying several methods simultaneously, requiring greater prudence to interpret the results.

\section{ACKNOWLEGDMENTS}

The authors thank FAPEMIG, CNPq and CAPES for the financial support and researcher at the Embrapa Rice and Beans Dr. Orlando Peixoto de Morais (in memoriam) and Paula Pereira Torga for their help. This study was financed in part by the Coordenação de Aperfeiçoamento de Pessoal de Nível Superior - Brasil (CAPES) - Finance Code 001.

\section{CONFLICTS OF INTEREST}

The authors declare no conflict of interest.

\section{REFERENCES}

Allard RW and Bradshaw AD (1964). Implications of genotype- environmental interactions in applied plant breeding. Crop Sci. 4(5): 503-508.

Barroso LMA, Nascimento M, Nascimento ACC, Silva FF, et al. (2015). Metodologia para análise de adaptabilidade e estabilidade por meio de regressão quantílica. Pesq. Agropec. Bras. 50(4): 290-297. doi: 10.1590/S0100204X2015000400004.

Barroso LMA, Nascimento M, Nascimento ACC, Silva FF, et al. (2013). Uso do método de eberhart e russell como informação a priori para aplicação de redes neurais artificiais e análise discriminante visando a classificação de genótipos de alfafa quanto à adaptabilidade e estabilidade. Rev. Bras. Biom. 31(2): 176-188.

Borges V, Soares AA, Reis MS, Resende MDV, et al. (2010). Desempenho genotípico de linhagens de arroz de terras altas utilizando metodologia de modelos mistos. Bragantia. 69(4): 833-841.

Cargnin A, Souza MA, Pimentel AJB and Fogaça CM (2008). Interação genótipos e ambientes e implicações na adaptabilidade e estabilidade de arroz sequeiro. Rev. Bras. Agroc. 14(3-4): 49-57. doi: HTTP://DX.DOI.ORG/10.18539/CAST.V14I3.1933.

Carneiro PCS. (1998). Novas metodologias de análise da adaptabilidade e estabilidade de comportamento. 168pp. Doctoral Thesis in Plant Genetics, Universidade Federal de Viçosa.

Carvalho CGP, Arias CAA, Toledo JFF, Almeida LA, et al. (2002). Interação genótipo x ambiente no desempenho produtivo de soja no Paraná. Pesq. Agropec. Bras. 37(7): 989-1000. doi: https://doi.org/10.1590/S0100204X2002000700013. 
Costa NHAD, Seraphin N JC and Zimmermann FJP (2002). Novo método de classificação de coeficiente de variação para a cultura do arroz de terras altas. Pesq. Agropec. Bras. 37(3): 243-249. doi: https://doi.org/10.1590/S0100204X2002000300003.

Conab, Companhia Nacional de Abastecimento. Available at: http://www.conab.gov.br. Accessed 01, January 2019.

Couto MF, Nascimento M, Amaral AT, Silva FFE, et al. (2015). Eberhart and Russel's Bayesian Method in the Selection of Popcorn Cultivars. Crop Sci. 55(2): 571. doi: 10.2135/cropsci2014.07.0498.

Cruz CD, Ferreia FM and Pessoni LA (2011). Biometria Aplicada ao Estudo da Diversidade Genética. Editora: Produção Independente, Viçosa.

Cruz CD and Carneiro PCS (2014). Modelos biométricos aplicados ao melhoramento genético. Vol 2. $3^{\text {rd }}$ ed. Editora UFV, Viçosa.

Cruz CD, Torres RA and Vencovsky R (1989). An alternative approach to the stability analysis proposed by Silva and Barreto. Rev. Bras. Genet. 12(3): 567-580.

Cruz CD (2016). Genes Software - extended and integrated with the R, Matlab and Selegen. Acta Sci. 38: 547-552. doi: 10.4025/actasciagron.v38i4.32629.

Cruz CD and Regazzi AJ (2012). Modelos biométricos aplicados ao melhoramento genético. Vol 1. $4^{\text {rd }}$ ed. Editora UFV, Viçosa.

Eberhart SA and Russell WA (1966). Stability parameters for comparing varieties. Crop Sci. 6(1): 36-40.

Finlay K and Wilkinson G (1963). The analysis of adaptation in a plant-breeding programme. Crop. Pasture Sci. 14: 742-754. doi: 10.1071/AR9630742.

Gauch HG, Piepho HP and Annicchiarico P (2008). Statistical analysis of yield trials by AMMI and GGE: Further considerations. Crop Sci. 48(3): 866-889. doi:10.1016/j.pbi.2013.02.014.

Godfray HCJ, Beddington JR, Crute IR, Haddad L, et al. (2010). Food security: The challenge of feeding 9 billion people. Science. 327(5967): 812-818. doi: 10.1126/ science.1185383.

Gomes FP (1990). Curso de estatística experimental. 13.ed. Piracicaba: Livraria Nobel, 467p.

Hosan SM, Sultana N, Iftekharuddaula KM, Ahmed MNU, et al. (2010). Genetic divergence in Landraces of Bangladesh rice (Oryza sativa L.). The Agriculturists 8(2): 28-34. doi: 10.3329/agric.v8i2.7574.

Irgsp (International Rice Genome Sequencing Project) (2005). The Map-Based Sequence of the Rice Genome. Nature. 436: 793-800. doi: 10.1038/nature03895.

Jacquemin J, Bhatia D, Singh K and Wing RA (2013). The International Oryza Map Alignment Project: Development of a Genus-Wide Comparative Genomics Platform to Help Solve the 9 Billion-People Question. Curr. Opin. Plant Biol. 16: 147-156. doi: 10.1016 / j.pbi.2013.02.014.

Lin CS and Binns MR (1988). A superiority measure of cultivar performance for cultivars x location data. Can. Jour. Plant Sci. 68(1): 193-198.

Muthayya S, Sugimoto JD, Montgomery S and Maberly GF (2014). An Overview of Global Rice Production, Supply, Trade, and Consumption. Ann. N. Y. Acad. Sci. 1324: 7-14. doi: 10.1111/nyas.12540.

Nascimento M, Ferreira A, Campana ACM, Salgado CC, et al. (2009). Multiple centroid methodology to analyze genotype adaptability. Crop Breed. Appl. Biotechnol. 62: 30-36.

Nascimento M, Silva FF, Safadi T, Nascimento ACC, et al. (2011). Abordagem bayesiana para avaliação da adaptabilidade e estabilidade de genótipos de alfafa. Pesq. Agropec. Bras. 46(1): 26-32. doi: https://doi.org/10.1590/S0100-204X2011000100004.

Nascimento M (2015). Multiple centroid method to evaluate the adaptability of alfalfa genotypes. Rev. Ceres. 62(1): 30 36. https://doi.org/10.1590/0034-737X201562010004.

Plaisted RL and Peterson LC (1959). A technique for evaluating the ability of selections to yield consistently in different locations or seasons. Am. Potato J. 36(11): 381-385.

Ramalho MAP, Santos JB and Zimmermann MJO (1993). Genética quantitativa em plantas autógamas: aplicações ao melhoramento do feijoeiro. Goiânia: UFG, 271 p.

Ramos LM, Sanches A, Cotes JM and Filho AC (2011). Adaptability and stability of yield rice genotypes, using two assessment methodologies in Colombia. Acta Sci. Agro. 60 (1): 39-49.

Ray DK, Mueller ND, West PC and Foley JA (2013). Yield trends are insufficient to double global crop production by 2050. PLoS ONE. 8(6): e66428. doi: 10.1371/journal.pone.0066428.

Resende MDV (2002). Genética biométrica e estatística no melhoramento de plantas perenes. Embrapa, Brasília. 975 p.

Resende MDV (2004). Métodos estatísticos ótimos na análise de experimentos de campo. Colombo: Embrapa Florestas. Doc. 100. p.57.

Rocha R, Muro-abad JI, Araujo EF and Cruz CD (2005) Avaliação do método centroide para estudo de adaptabilidade ao ambiente de clones de Eucalyptus grandis. Ciencia. Florestal. 15(3): 255-266.

Santos IG, Carnairo VQ, Silva Junior AC, Cruz CD, et al. (2019). Self-organizing maps in the study of genetic diversity among irrigated rice genotypes. Acta Sci. Agron. v. 41. doi:10.4025/actasciagron.v41i1.39803.

Silva FL, Soares PC, Cargnin A, Souza MA, Soares AA, et al. (2008). Methods of adaptability and stability analysis in irrigated rice genotypes in Minas Gerais, Brazil. Crop Breed. Appl. Biotechnol. 8: 119-126, 2008. 
Silva GN, Silva Junior, AC, Sant'anna IC, Cruz CD et al. (2019). Projeção de distâncias como método auxiliar na classificação de arroz irrigado quanto a adaptabilidade e estabilidade. Rev. Bras. Biom. 37(2): 229-243. doi: $10.28951 / \mathrm{rbb} . \mathrm{v} 37 \mathrm{i} 2.383$.

Silva RR and Benin G (2012). Análises Biplot: conceitos, interpretações e aplicações. Cienc. Rural. 42(8): 1404-1412. doi: https://doi.org/10.1590/S0103-84782012000800012.

Soares PC, Melo PGS, Melo LC and Soares AA (2005). Genetic gain in an improvement program of irrigated rice in Minas Gerais. Crop Breed. Appl. Biotechnol. 5: 142-148.

Streck EA, Aguiar GA, Magalhães Júnior AM, Facchinello HK, et al. (2017). Variabilidade fenotípica de genótipos de arroz irrigado via análise multivariada. Rev. Cienc. Agron. 48(1): 101-109. doi: 10.5935/1806-6690.20170011.

Streck EA, Magalhães Júnior AM, Fagundes PRR, Aguiar GA, et al. (2018). Adaptability and stability of flood-irrigated rice cultivars released to the subtropical region of Brazil. Pesq. Agrop. Bras. 53(10): 1140-1149. https://doi.org/10.1590/s0100-204x201800100000.

Tai GCC (1971). Genotypic Stability Analysis and Its Application to Potato Regional Trials. Crop Sci. 11(2): 184. DOI:10.2135/cropsci1971.0011183X001100020006x.

Walter M, Marchezan E and Avila LA (2008). Arroz: composição e características nutricionais. Ciênc. Rural. 38(4): 1184-1192. doi: https://doi.org/10.1590/S0103-84782008000400049.

Wricke G (1965). Zur Berechnung der Ökovalenz bei Sommerweizen und Hafer. Pflanzenzuchtung. 52(1): 127-138.

Yan W and Kang MS (2003). GGE Biplot Analysis: A Graphical Tool for Breeders, Geneticists and Agronomists. CRC Press, Boca Raton, FL, USA, 271p.

Yan W and Tinker A (2006). Biplot analysis of multi environment trial data: principles and applications. Can. J. Plant Sci. 86(3): 623-645.

Yan W, Kang MS, Ma B, Woods S, et al. (2007). GGE biplot vs. AMMI analysis of genotype-by-environment data. Crop Sci. 47(2): 643-653. doi: 10.2135/cropsci2006.06.0374.

Yan W (2011). GGE Biplot vs. AMMI Graphs for Genotype-by-Environment Data Analysis. J. India Soc. Agri. Sta. 65(2): 181-193.

Zhang Q and Wing RA (2013). Genetics and Genomics of Rice: 2013. Springer, New York Heidelberg Dordrecht London, 402 p. doi: 10.1007/978-1-4614-7903-1.

Zhou Y, Yang P, Cui F, Zhang F, et al. (2016). Transcriptome analysis of salt stress responsiveness in the seedlings of Dongxiang wild rice (Oryza rufipogon Griff.). PLoS ONE. 11: 146-242. doi: 10.1371/journal.pone.0146242. 